Сергій Сінкевич, кандидат педагогічних наук, доцент Національна академія Державної прикордонної служби України імені Богдана Хмельницького ORCID ID 0000-0001-5838-2177

Сергій Серховець, кандидат педагогічних наук Національна академія Державної прикордонної служби України імені Богдана Хмельницького ORCID ID 0000-0002-1439-1300 DOI: $10.33099 / 2617-1775 / 2020-01 / 264-270$

\title{
ОСОБЛИВОСТІ ОРГАНІЗАЦІЇ НАСТАВНИЦЬКОЇ ДІЯЛЬНОСТІ НА КАФЕДРАХ ВІЙСЬКОВО-СПЕЦІАЛЬНОЇ СПРЯМОВАНОСТІ ВІЙСЬКОВОГО ЗАКЛАДУ ВИЩОЇ ОСВІТИ ДЕРЖАВНОЇ ПРИКОРДОННОЇ СЛУЖБИ УКРАЇНИ
}

У статті представлено організаційнізаходинаставнищької діяльності, спрямованоїна подання інтерактивної допомоги у професійному розвитку науково-педагогічного складу кафедр військово-спеціальної спрямованості.Через запропонованізаходи визначеноосновні напрями міжособистісної взаємодії: оптимізачія професійної діяльності,конкретизачія професійних завдань, інтенсифікаціята регламентаціязаходів відповідно до посадових обов'язків,своєчасність реагування, фіксачія результатів.

Ключові слова: військовий заклад вищої освіти; військово-спечіальна спрямованість; Державна прикордонна служба України; кафедра; наставнищька діяльність; організація; особливості.

Постановка проблеми. На посади науково-педагогічного складу закладів освіти Державної прикордонної служби України призначаються офіцери та цивільні працівники зі значним досвідом виконання професійних функцій на державному кордоні (в районі проведення операції Об'єднаних сил), які не мають педагогічної освіти. Професійна підготовка зазначеної категорії військовослужбовців та працівників кафедр військово-спеціальної спрямованості факультету охорони та захисту державного кордону Національної академії Державної прикордонної служби України імені Богдана Хмельницького (далі - НАДПСУ) до виконання завданьза посадовими інструкціями відбуваєтьсяпоетапно за усталенималгоритмом: навчання у «школі педагогічної майстерності» - початкова професійно-педагогічна підготовка;організація та проведення пробного заняття - «допуск» до самостійного виконання військово-педагогічних завдань;педагогічне стажування та самоосвіта - опанування особливостей проведення різних видів занять (інших аудиторних і позааудиторних заходів); творчо-науковий пошук визначення напрямів удосконалення освітнього процесу відповідно до отриманих компетентностей під час опрацювання наукових робіт на здобуття наукових ступенів і вчених звань; апробація та реалізація на практиці освітнього процесу результатів кваліфікаційних (наукових) робіт. 
Поряд із зазначеним констатуємо наявність певних професійнопедагогічних труднощів, на які натрапляють як викладачі-початківці, так і досвідчені педагоги (після опрацювання тридцяти чотирьох анкетопитувальниківщодо труднощів, що виникали унауково-педагогічного складу кафедр військово-спеціальної спрямованості, нами представлено результати відповідно до наданих їм рангових місць; крім того, персоналом кафедр сформульовано й власні позиції у цьому контексті): реалізація на практиці розподілу робочого часу за навчальною, методичною, науковою й організаційною діяльністю; конкретизація професійних завданьшляхом підготовки та затвердження особистого плану роботи викладача на місяць; щоденний розподіл часу на вирішення питань професійної діяльності; реалізація в освітньому процесі результатів аналізу обстановки на кордоні, а такожінновацій і змін, передбачених законодавчими актамита внутрішньовідомчими документами;підготовка звіту про виконання індивідуального плану роботи викладача й ії обліку. Гіпотетично, подолання цих труднощів буде тим ефективнішим, чим ефективнішим буде організовано міжособистісну взаємодію персоналу зазначених кафедр.

Аналіз останніх досліджень i публікацій. Питанням військовоспеціальної та професійно-педагогічної підготовки науково-педагогічного складу кафедр військово-спеціальної спрямованостізакладів освіти Державної прикордонної служби України присвячено наукові роботи А. Галімова, О. Діденка, Д. Іщенка, А. Мельнікова, Б. Олексієнка, О. Торічного; особливості професійної підготовки офіцерів-прикордонників у магістратурі та на курсах підвищення кваліфікаціїрозглядалися в науково-методичних працях В. Веретільника, О. Луцького, В. Райка, Т. Суслова; методичні аспекти використання науково-педагогічним складом аудиторної та польової навчально-матеріальної бази НАДПСУ представлено в роботах В. Березюка, В. Гаврилюка, Ю. Кузя, О. Заболотної та інших.Проте, наукових досліджень, у яких було б висвітлено комплексні підходи до вирішення проблем і труднощів післядипломної підготовки (перепідготовки) науково-педагогічного складу кафедр військово-спеціальної спрямованості,практично немає. Не складає виключення й наставницький підхід до подолання труднощів військовими педагогами у контексті визначеної проблеми: актуалізує цей напрям дослідження нагальна необхідність обміну досвідом між досвідченими педагогами (використання педагогічних технологій,методик і методичних прийомів викладаннянавчальних дисциплін, результатів наукових пошуківтощо) та викладачами-початківцями (використання офіцерамиприкордонниками отриманих у закладах вищої освіти компетентностей під час організації та здійснення заходів 3 охорони й оборони державного кордону, а також виконання інших професійних завдань, покладених законодавством на органи та підрозділи Державної прикордонної служби України).

Метою статті є конкретизувати організаційні заходи наставницької діяльності, що визначають основні напрями міжособистісної взаємодії науковопедагогічного складу кафедр військово-спеціальної спрямованості. 
Методи дослідження - аналіз і синтез результатів теоретичних та емпіричних наукових доробок за напрямом дослідження.

Виклад основного матеріалу. Професійна підготовка майбутніх офіцерів-прикордонників здійснюється на базі НАДПСУ - єдиного військового закладу вищої освіти Державної прикордонної служби України. Провідна роль у наданні освітніх послуг зазначеній категорії військовослужбовців належить факультету охорони та захисту державного кордону- кафедрам військовоспеціальної спрямованості: тактики прикордонної служби, прикордонного контролю, кінології, загальновійськових дисциплін, фізичної підготовки та особистої безпеки, вогневої та тактико-спеціальної підготовки.

3 метою якісної організації та проведення всіх видів занять науковопедагогічним складом цих кафедр здійснюється комплекс заходів (науковометодичні конференції, науково-педагогічне стажування, міжкафедральні наради, обмін досвідом, взаємне відвідування занять, «круглі столи», навчання у «школі педагогічної майстерності», пробні й інструкторсько-методичні заняття, рекогносцировка польової навчально-матеріальної бази, контроль занять відповідними посадовими особами, методичний супровід самостійної підготовки й інші), спрямованих на підтримання належного методичного рівня викладання навчальних дисциплін. Серед інших науково-методичних заходів одним із найбільш ефективних, на нашу думку, є організація та здійснення наставницької діяльності.

$\mathrm{y}$ сучасних дослідженнях достатньо повно розкрито поняття наставництва, під яким розуміють підтримку та наснаження молодої особистості на шляху розвитку власного потенціалу та навиків, а також вибору

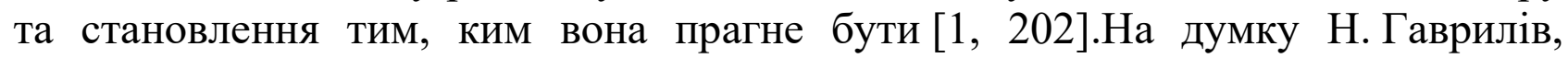
наставникділиться з підопічним мудрістю, знаннями та підтримує його в спосіб, який він здатний найефективніше сприйняти та 3 якого зможе отримати найбільшукористь. Традиційно, за результатами аналізу наукових доробок за визначеним напрямом дослідниця акцентує увагу на ролях, що має наставник: тренер, довірена особа, друг, провідник, слухач, партнер, натхненник,вчитель $[1,202]$.

Крім того, погоджуємося з Є. Дудіною щодопредставлених змістовних характеристикнаставництва поза залежністю від контексту його практичної реалізації: цілеспрямованість, суб'єктність, орієнтація на потреби та самореалізацію, взаємоспрямованість, добровільність, прийняття своєї ролі наставником і підопічним, розвивальний і взаємозбагачувальний потенціал, автентичність навчального та розвивального середовища в спільній діяльності, єдність трьох збільшених функцій (психосоціальної, інструментальної й еталонної), довготривалість[2].

Отже, наставницька діяльність на кафедрах вищих військових навчальних закладів полягає в організації міжособистісної взаємодії між досвідченими, методично грамотними, всебічно розвиненими військовими педагогами та викладачами-початківцями, діяльність яких спрямовується на оптимізацію всіх галузей їх спільної професійно-освітньої діяльності. Загальні положення щодо організаціїзаходів наставницької діяльності у НАДПСУ окреслено Положенням 
про наставництво в органах та підрозділах Державної прикордонної служби України [3].

Представимо докладну характеристику організаційних заходів наставницької діяльності, що, на нашу думку, визначають основні напрями міжособистісної взаємодії науково-педагогічного складу кафедр військовоспеціальної спрямованості. За ранговими показниками перше місце науковопедагогічним складом надано «оптимізації професійної діяльності». Одразу після призначення на посади науково-педагогічного складу військовий або цивільний педагог опрацьовуєіндивідуальний планроботи викладача й їі обліку. Очевидно, без допомоги наставника якісно це завдання виконати він немає можливості. 3 урахуванням досвіду виконання обов'язків у підрозділах охорони кордону викладача-початківця та проведення наставником всіх видів занять, а також інших освітніх заходівспільними зусиллями здійснюється відбір тем та видів занять, які слугували 6 сполучною ланкою для ефективного введенняпідопічного до науково-педагогічної діяльності(забезпечується внесення пропозицій щодо розподілу робочого часу за навчальною, методичною, науковою й організаційною діяльністю 3 урахуванням професійно-важливих якостей i практичного досвіду- підготовка та затвердження індивідуального плану роботи викладача й їі обліку).

Навчання у «школі педагогічної майстерності» відбувається паралельно 3 викладацькою діяльністю, яка починається після успішного проведення викладачем-початківцем пробного заняття, до якого у якості тих, хто навчається, залучається весь науково-педагогічний склад кафедри та керівництво факультету; організаційно-підготовчі заходи цього важливого «кар'єрного кроку» забезпечуються наставником. Найближчою перспективою професійної діяльності для підопічного є конкретизація професійних завдань підготовка особистого плану роботи на місяць та, за необхідності, своєчасне внесення до нього змін. Зміни, як правило, пов'язані з виконанням інших професійних обов'язків військовими педагогами кафедри: стажування, професійно-орієнтаційна робота, відрядження тощо.

Наставник за погодженням 3 начальником кафедри забезпечує щоденний розподіл часу та спрямування дій підопічного на вирішення питань професійної діяльності: відбувається інтенсифікація та чіткарегламентація заходів відповідно до посадових обов’язків. Крім того, поступово викладач-початківець перебудовуєкомандний стиль діяльності на викладацький: значної уваги приділяє підготовці навчально-методичних матеріалів, основу яких під час викладання навчального матеріалу складає досвід служби на кордоні (конкретні приклади результатів виконання оперативно-службових і бойових завдань).

Поряд із цим, освітній процес у НАДПСУ нині характеризується швидкоплинністю та суттєвими змінами в організації та здійсненні всіх його складових, що в свою чергу вимагає від науково-педагогічного складу своєчасногота творчогореагування на директивні інновації. Результати власних досліджень дають можливість зафіксувати основні шляхи реалізації в освітньому процесі зазначених змін: запровадження щоденного вивчення аналітичних довідок щодо обстановки на кордоні та в районах проведення 
операції Об'єднаних сил, використання зовнішніх (Інтернет) і внутрішніх (Інтранет) мережевих ресурсів для моніторингу інновацій і змін, передбачених законодавчими актами, а також внутрішньовідомчими документами; постійний обмін інформацією між відповідними посадовими особами та в колективах кафедр.

Важливими заходами міжособистісної взаємодії наставника та підопічного є підготовка, обговорення на кафедрі та протокольне затвердження звіту про виконання індивідуального плану роботи викладача й іiї обліку на семестр і навчальний рік - відбувається підбиття підсумків освітньої діяльності шляхом фіксації результатів. Крім того, підготовка звіту про наукову діяльність - щокварталу та за календарний рік. За результатами опрацювання звітних матеріалів забезпечується оприлюднення на сайті НАДПСУ рейтингу науково-педагогічного складу - фактичних досягнень військових та цивільних педагогів.

Висновки. За результатами аналізу теорії та практики ведення освітнього процесу в НАДПСУ уточнено й конкретизовано організаційні заходи наставницької діяльності науково-педагогічного складу кафедр військовоспеціальної спрямованості: оптимізація професійної діяльності, конкретизація професійних завдань, інтенсифікація та регламентація заходів відповідно до посадових обов'язків, своєчасність реагування на інноваціїта зміни у законодавчих актах і внутрішньовідомчих документах, фіксація результатів виконання індивідуального плану роботи викладача й iї обліку на семестр і навчальний рік, а також наукової діяльності щокварталу та за календарний рік.

Напрями подалыших досліджень. Доцільним напрямом продовження наукових пошуків автори вбачають у розробці комплексної структурнофункціональної моделі організації та здійснення наставницької діяльності у військових закладах освіти Державної прикордонної служби України, а також організаційно-педагогічних умов i шляхів забезпечення iіi реалізації на практиці.

\section{ЛIТЕРАТУРА}

1. Гаврилів Н. Наставництво як інструмент сучасної освіти / Наталія Гаврилів //“HUMANITIES \& SOCIAL SCIENCES 2009” (HSS-2009), 14-16 MAY 2009, LVIV, UKRAINE. - C. 201-202.

2. Дудина Е. А. Наставничество как особый вид педагогической деятельности / Е. А. Дудина // Вестник Новосибирского государственного педагогического университета, 2007, том 7, №5. - С. 29.

3. Положення про наставництво в органах та підрозділах Державної прикордонної служби України: затверджено наказом Адміністрації Державної прикордонної служби України від 22.03.2010 № 205. - 9 с.

\section{REFERENCES}

1. Havryliv, N. (2009). Struktura hotovnosti vchytelia fizychnoho vykhovannia do innovatsiinoi navchalnoi diialnosti [Mentoring as an instrument of modern education]. “HUMANITIES \& SOCIAL SCIENCES 2009” (HSS-2009), 201-202 (in Ukrainian). 
2. Dudina, E. A. (2007). Nastavnichestvo kak osoby`j vid pedagogicheskoj deyatel’nosti [Mentoring as a special kind of pedagogical activity]. Vestnik Novosibirskogo gosudarstvennogo pedagogicheskogo universiteta, tom 7, \#5, 29 (in Russian).

3. Polozhennia pro nastavnytstvo $\mathrm{v}$ orhanakh ta pidrozdilakh Derzhavnoi prykordonnoi sluzhbyUkrainy[Manual on mentoring in organs and units of State Border Guard Service of Ukraine]. Zatverdzheno nakazom Administratsii Derzhavnoi prykordonnoi sluzhby Ukrainy vid 22.03.2010 № 205, 9 (in Ukrainian).

\section{PЕЗЮМЕ}

Сергей Синкевич, кандидат педагогических наук, доцент Национальная академия Государственной пограничной службы Украины имени

Богдана Хмельницкого

Сергей Серховец, кандидат педагогических наук Национальная академия Государственной пограничной службы Украины имени

Богдана Хмельницкого

\section{Особенности организации наставнической деятельности на кафедрах военно- специальной направленности военного учреждения высшего образования Государственной Пограничной службы Украины}

В статье представлень организачионные мероприятия наставнической деятельности, направленной на представление интерактивной помощи в профессиональном развитии научно-педагогического состава кафедр военно-специальной направленности. По предложенным мероприятиям определены основные направления межличностного взаимодействия: оптимизация профессиональной деятельности, конкретизация профессиональных задач, интенсификация и регламентация мероприятий в соответствии с должностными обязанностями, своевременность реагирования, фиксация результатов.

Ключевые слова: военное учреждение высшего образования; военно-спечиильная направленность; Государственная пограничная служба Украины; кафедра; наставническая деятельность; организация; особенности.

\section{SUMMARY}

Serhiy Sinkevych, candidate of pedagogical sciences, associate professor

National Academy of State Border Guard Service of Ukraine named after Bohdan Khmelnytskyi Serhiy Serkhovets, candidate of pedagogical sciences National Academy of State Border Guard Service of Ukraine named after Bohdan Khmelnytskyi higher education establishment of the state border Guard service of Ukraine 
Introduction. Officers and civilians with significant experience in performing professional functions at the state border (in the area of the United Forces operation) who do not have a pedagogical education are assigned to the posts of scientific and pedagogical staff of the State Border Guard Education Institutions of Ukraine.

The purpose of the article is to specify the organizational measures of mentoring activity that determine the main directions of interpersonal interaction of the scientific and pedagogical composition of the departments of military specialization.

Research methods are analysis and synthesis of results of theoretical and empirical scientific achievements in the field of research.

Originality. There are practically no scientific researches in which the complex approaches to solving problems and difficulties of postgraduate training (retraining) of the scientific and pedagogical staff of the departments of military specialization would be covered. The mentoring approach to overcoming the difficulties of military lecturers in the context of a certain problem is also an exception.

Conclusion. The organizational measures for mentoring activities aimed at providing an interactive assistance by the scientific and pedagogical staff of the military special orientation departments within a professional development in the system "experienced lecturer - novice lecturer» have been presented in the article.

Through out of the proposed mentoring activity organizational measures the main directions of interpersonal interaction of the military special orientation departments scientific and pedagogical staff have been determined: professional activity optimization (making proposals on the distribution of working time by educational, methodical, scientific and organizational activities, taking into account professionally important qualities and practical experience - preparation and approval of the individual plan of work of the lecturer and its accounting), specification of professional tasks (preparation of a personal work plan for a month, introduction of changes timely), intensification and regulation of activities in line with responsibilities (daily clear timing and directing action to carry out professional activity), timeliness response (the results of the situation at the border analysis implementation within the educational process, the usage of network resources for monitoring innovations and changes in legislative acts and intradepartmental documents), results fixing (preparation, discussion at the department and protocol approval of the report on the implementation of the individual work plan of lecturing for the semester and the academic year, as well as the report on scientific activity - quarterly and for the calendar year).

The authors see the expedient direction of continuation of scientific research in the development of a comprehensive structural and functional model of organization and implementation of mentoring activities in the military educational institutions of the State Border Service of Ukraine, as well as organizational and pedagogical conditions and ways of ensuring its implementation in practice.

Key words: military higher education establishment; military and special orientation; State Border Guard Service of Ukraine; department; mentoring; organization; features. 